\title{
ANTIHYPERTENSIVE EFFECTS OF NIGELLA SATIVA: WEIGHING THE EVIDENCE
}

\section{ANGGA WIRATAMA LOKESWARA ${ }^{1}$, KEVIN AFARATU ${ }^{1}$, RAFINDHRA ADHITYA PRIHASTAMA ${ }^{1}$, SITI FARIDA ${ }^{2 *}$}

1Faculty of Medicine, Universitas Indonesia, Jakarta, Indonesia, ${ }^{2}$ Department of Medical Pharmacy, Universitas Indonesia, Jakarta, Indonesia

Email: siti.farida@ui.ac.id

Received: 14 Dec 2018, Revised and Accepted: 10 Mar 2019

\section{ABSTRACT}

Objective: Hypertension causes 7.5 million deaths annually worldwide. Antihypertensive drugs cause side effects, potentially leading to nonadherence, hence uncontrolled hypertension and increased risk of cardiovascular morbidity and mortality. Therefore, there has been increasing interest in alternative pharmacological treatments for hypertension, one of which is black cumin, or Nigella sativa, a traditional medicine that has been empirically used. This evidence-based case report aims to evaluate the current evidence for the effectiveness of Nigella sativa in reducing blood pressure in a mildly hypertensive patient.

Methods: A literature search was performed on MEDLINE, TRIP Database, Clinical Key, ScienceDirect, and DynaMed, using the keywords "nigella sativa", "hypertension", and "blood pressure" with all their synonyms and related terms. The included studies were two systematic reviews and two clinical trials, which were then critically appraised.

Results: Out of the four studies, three were considered valid. In terms of importance, Sahebkar et al. showed a reduction of the weighted mean difference (WMD) by Nigella sativa: $-3.26 \mathrm{mmHg}, 95 \% \mathrm{CI}:-5.10,-1.42$, I $=59 \%$ for systolic blood pressure and WMD: $-2.80 \mathrm{mmHg}$, $95 \%$ CI: -4.28 , $-1.32, \mathrm{I}^{2}=60 \%$ for diastolic blood pressure. Badar et al. concluded that Nigella sativa significantly reduced systolic and diastolic blood pressure compared with the control group. Two studies were considered applicable to our patient in question.

Conclusion: The current evidence for the effect of Nigella sativa in lowering blood pressure is limited. However, one study gives strong evidence for significant antihypertensive effects of Nigella sativa. In mild hypertension, Nigella sativa could be one of the therapeutic options.

Keywords: Hypertension, Blood pressure, Nigella sativa, Black seed, Black cumin

(C) 2019 The Authors. Published by Innovare Academic Sciences Pvt Ltd. This is an open access article under the CC BYlicense (http://creativecommons. org/licenses/by/4. 0/) DOI: http://dx.doi.org/10.22159/ijap.2019.v11s6.33577

\section{INTRODUCTION}

Hypertension, or high blood pressure, is a condition in which elevated pressure persists within the blood vessels. The pressure in the blood vessels is created by blood flow that forces against the inner walls of the vessels. The latest data from the World Health Organization shows that hypertension is estimated to cause 7.5 million deaths annually or about $12.8 \%$ of all deaths worldwide. It also causes 57 million disability adjusted life years (DALYs) or about $3.7 \%$ of total DALYs [1] The prevalence of this non-communicable disease is rising in developing countries, and in Indonesia, which is the fourth most populous country in the world. The burdens of diabetes, heart disease, stroke, and hypertension have increased in the past $20 \mathrm{y}$. According to Indonesian Basic Health Research (or Riset Kesehatan Dasar), the prevalence of hypertension in Indonesia was 25.8\% in 2013. According to Sample Registration System Indonesia, hypertension with complications accounted for about $5.3 \%$ of all deaths in Indonesia in 2014, making it the fifth highest cause of death [2, 3]. Moreover, the burden of hypertension also comes from the low rate of diagnosis and treatment. Only $1 / 3$ of patients with hypertension have been diagnosed, while only $0.7 \%$ of those diagnosed with hypertension are taking antihypertensive medications [3].

Currently, the available treatments for hypertension include various classes of antihypertensive drugs, such as angiotensin-converting enzyme inhibitors, angiotensin II receptor blockers, calcium channel blockers, and thiazide-type diuretics [4]. In a prospective cohort study in the United States, side effects of antihypertensive drugs occurred in $85 \%$ of the patients, resulting in non-adherence of $34.5 \%$ of patients to the treatments.[5] Such non-adherence is believed to be the main cause of uncontrolled hypertension, which then increases the risk of heart failure, stroke, and mortality [6, 7] The adverse effects of these drugs along with the relatively high costs, have contributed to the rising interest in herbal treatment for hypertension [8].

Nigella sativa, also known as black cumin, black seed, habitus sauda, or jintan hitam in Indonesia, is a traditional medicine that has been used in various medical conditions since hundreds of years ago [9]. Preclinical and clinical studies have suggested $N$. sativa as antioxidants and diuretic agents, and its effects in reducing sympathetic activities, lowering lipids, increasing nitric oxide production to prevent arterial rigidity, reducing appetite and many others, all of which contribute to its potential use as an antihypertensive agent [10-12]. However, despite its empirical use through generations, the scientific evidence on the antihypertensive effects of $N$. sativa is somehow limited and often inconsistent. Therefore, this evidence-based case report aims to critically analyze and weigh the available evidence for the effects of $N$. sativa on alleviating hypertension.

\section{Clinical question}

A 45-year-old man participated in a blood pressure screening program. His blood pressure reading was $130 / 90 \mathrm{mmHg}$. He and his immediate family had no history of cardiovascular diseases. The patient was interested to know if he could use $N$. sativa supplements to control his blood pressure.

\section{MATERIALS AND METHODS}

A search of literatures was performed on September 15th to 16th, 2018 on MEDLINE, TRIP Database, Clinical Key, ScienceDirect, and DynaMed. The keywords used were "nigella sativa", "hypertension" and "blood pressure" with all their synonyms and related terms. Table 1 below shows the terminology used in each database during the search.

The eligible articles were clinical trials, systematic reviews and meta-analyses with blood pressure (systolic and diastolic) as one of the outcomes of the study, limited to studies in human and published in English in the last 5 y. All guidelines and review articles were excluded. The search strategy is illustrated in fig. 1. After screening the literatures and reading the full texts, therapy articles or systematic reviews were critically appraised with consensus of all authors based on the guideline established by the Center of Evidence-Based Medicine, University of Oxford. 
Table 1: Search terms used in the five databases

\begin{tabular}{|c|c|c|c|}
\hline Database & Terminology & Hits & Selected \\
\hline MEDLINE & $\begin{array}{l}\text { (((hypertension) OR blood pressure) AND nigella sativa) AND ((Review[ptyp] OR Meta-Analysis[ptyp] OR } \\
\text { Randomized Controlled Trial[ptyp] OR Controlled Clinical Trial[ptyp] OR Clinical Trial[ptyp]) AND "last } 5 \\
\text { y"[PDat]) }\end{array}$ & 15 & 3 \\
\hline $\begin{array}{l}\text { Trip } \\
\text { database }\end{array}$ & (hypertension)(nigella sativa)(blood pressure) & 13 & 0 \\
\hline ClinicalKey & ((Nigella sativa) OR 'blood pressure') AND 'nigella sativa' & 21 & 0 \\
\hline ScienceDirect & TITLE-ABSTR-KEY(“hypertension” OR “blood pressure”) AND TITLE-ABSTR-KEY (nigella sativa) & 6 & 0 \\
\hline DYNAMED & ((Nigella sativa) OR 'blood pressure') AND 'nigella sativa' & 3 & 1 \\
\hline
\end{tabular}

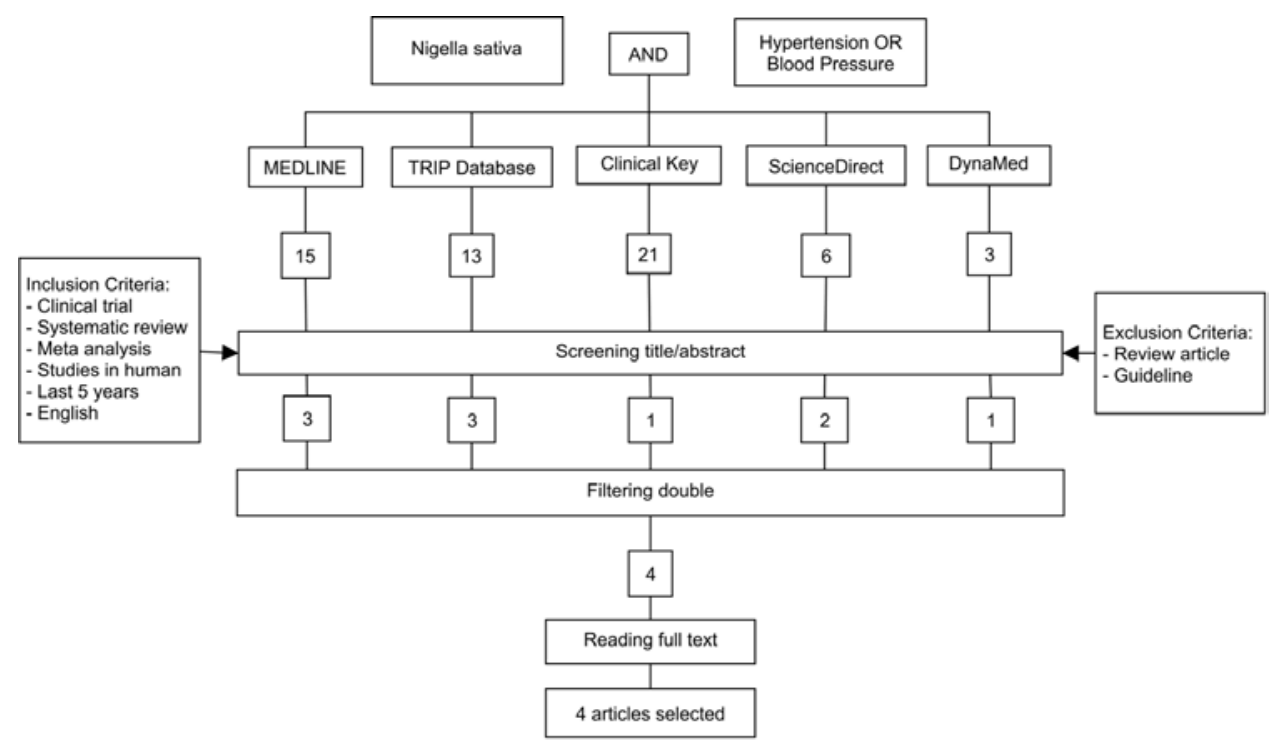

Fig. 1: Flowchart of the search strategy

\section{RESULTS}

Following the literature search, four articles were found to be eligible for this evidence-based case report [13-16] the design and summary of the articles can be found in table 2 .

These two articles are prospective cohort studies with a level of evidence of 2b. The study by Badar A, et al. [13] has a larger sample size and longer duration compared with the study by Rizka A, et al. [14]. The former is a single-blind non-randomized clinical trial, whereas the latter is a double-blind randomized controlled trial. The remaining two articles chosen are systematic reviews, the critical appraisal of which is explained in table 4. The review by Sahebkar A, et al. [15] includes a meta-analysis, while the review by Mohtashami A, et al. does not [16].

Table 2: Summary of the selected articles

\begin{tabular}{|c|c|c|c|c|}
\hline & Badar, et al. (2017) & Rizka, et al. (2017) & Sahebkar, et al. (2016) & Mohtashami, et al. (2016) \\
\hline Type of Studies & $\begin{array}{l}\text { Non-randomized, } \\
\text { single-blind } \\
\text { clinical trial }\end{array}$ & $\begin{array}{l}\text { Randomized, } \\
\text { double-blind } \\
\text { clinical trial }\end{array}$ & $\begin{array}{l}\text { Systematic review } \\
\text { and meta-analysis } \\
\text { of randomized } \\
\text { controlled trials }\end{array}$ & Systematic review of clinical trials \\
\hline Subjects/Materials & $\begin{array}{l}\text { Patients with } \\
\text { type } 2 \text { diabetes } \\
\text { and hypertension } \\
57 \text { patients in } \\
\text { each group, } \\
\text { total of } 114\end{array}$ & $\begin{array}{l}\text { Advanced-age } \\
\text { patients with } \\
\text { hypertension } \\
38 \text { patients in } \\
\text { each group, } \\
\text { total of } 76\end{array}$ & $\begin{array}{l}\text { Hypertensive and normotensive } \\
\text { patients; pooled total of } 860 \\
\text { patients } 11 \text { RCTs from PubMed, } \\
\text { Medline, Cochrane Collaboration } \\
\text { Library, SCOPUS, Web of Science, } \\
\text { and Google Scholar }\end{array}$ & $\begin{array}{l}\text { Patients with diabetes, patients with } \\
\text { metabolic syndrome, patients with } \\
\text { hyperlipidemia, patients with hypertension, } \\
\text { and healthy subjects; pooled total of } 1531 \\
\text { PubMed, Google Scholar, Thomas Reuters } \\
\text { Web of Science, and Cochrane }\end{array}$ \\
\hline Intervention & $\begin{array}{l}\text { N. sativa } \\
\text { seeds: } 500-\mathrm{mg} \\
\text { oral capsules, } 2 \\
\text { g/day for } 12 \mathrm{mo}\end{array}$ & $\begin{array}{l}\text { N. sativa seeds: } \\
300 \text {-mg oral } \\
\text { capsules, } 2 \text { times } \\
\text { a day for } 28 \mathrm{~d}\end{array}$ & $\begin{array}{l}\text { N. sativa oil }(\mathrm{n}=3) \\
\text { N. sativa } \\
\text { powder }(\mathrm{n}=8)\end{array}$ & $\begin{array}{l}N \text {. sativa extract } N \text {. sativa oil } \\
N \text {. sativa powder Dose of } 200 \mathrm{mg} \text { to } 5 \mathrm{~g} \text {. } \\
\text { Duration of } 2 \mathrm{w} \text { to } 6 \text { mo }\end{array}$ \\
\hline Control & $\begin{array}{l}\text { Placebo (activated } \\
\text { Charcoal capsules) }\end{array}$ & Placebo & $\begin{array}{l}\text { Placebo }(n=10) \\
\text { Standard treatment }(n=1)\end{array}$ & Not clear \\
\hline Results & $\begin{array}{l}\text { Significant } \\
\text { decrease in SBP, } \\
\text { DBP, and MAP }\end{array}$ & $\begin{array}{l}\text { Clinically } \\
\text { Significant } \\
\text { decrease in SBP } \\
\text { but not DBP }\end{array}$ & $\begin{array}{l}\text { Short-term } \\
\text { treatment with } N \text {. sativa } \\
\text { significantly reduced SBP } \\
\text { and DBP }\end{array}$ & $\begin{array}{l}\text { N. sativa at different doses and for different } \\
\text { durations can change various clinical and } \\
\text { biochemical parameters, but less } \\
\text { pronounced effect on blood pressure }\end{array}$ \\
\hline
\end{tabular}

RCTs, randomized controlled trials; SBP, systolic blood pressure; DBP, diastolic blood pressure; MAP, mean arterial pressure, Out of the four articles chosen, two articles are original articles, the critical appraisal of which is shown in table 3. 
Table 3: Critical appraisal of the two clinical trials

\begin{tabular}{|c|c|c|c|}
\hline & & Badar A, et al. (2017) & Rizka A, et al. (2017) \\
\hline Level of evidence & & $2 \mathrm{~b}$ & $2 \mathrm{~b}$ \\
\hline Sample size & & 114 & 76 \\
\hline Length of treatment & & $12 \mathrm{mo}$ & $28 \mathrm{~d}$ \\
\hline \multirow[t]{6}{*}{ Validity } & Randomization & - & + \\
\hline & Group similarity & + & $?$ \\
\hline & Equal treatment & + & + \\
\hline & Loss to follow-up (\%) & 15.8 & $\mathrm{~N} / \mathrm{A}$ \\
\hline & Drop-out (\%) & $\mathrm{N} / \mathrm{A}$ & 9.2 \\
\hline & Blinding & Single & Double \\
\hline \multirow[t]{6}{*}{ Importance } & Changes in blood pressure & Systolic BP: & Systolic BP: \\
\hline & (endpoint compared with baseline) & $9.66 \mathrm{mmHg}$ & $14.6 \mathrm{mmHg}$ \\
\hline & & Diastolic BP: & Diastolic BP: \\
\hline & & $3.51 \mathrm{mmHg}$ & $3.9 \mathrm{mmHg}$ \\
\hline & P values (treatment vs placebo) & Systolic BP: 0.053 & Systolic BP: 0.36 \\
\hline & & Diastolic BP: 0.024 & Diastolic BP: 0.35 \\
\hline \multirow[t]{3}{*}{ Applicability } & Patient similarity & + & + \\
\hline & Feasibility of treatment & + & + \\
\hline & Benefits outweigh harm & + & + \\
\hline
\end{tabular}

+shown clearly in the article; - not being done;? not stated clearly; levels of evidence based on Oxford Centre for Evidence-Based Medicine; BP: blood pressure

Table 4: Critical appraisal of the two systematic reviews

\begin{tabular}{|c|c|c|}
\hline Validity & Sahebkar, et al. (2016) & Mohtashami, et al. (2016) \\
\hline $\begin{array}{l}\text { Did the systematic review address a } \\
\text { relevant question? }\end{array}$ & Yes & Yes \\
\hline $\begin{array}{l}\text { Were the criteria used to select } \\
\text { articles for inclusion appropriate? }\end{array}$ & Yes & Yes \\
\hline $\begin{array}{l}\text { Is it likely that important, relevant } \\
\text { studies were missed? }\end{array}$ & No & No \\
\hline $\begin{array}{l}\text { Was the validity of the selected } \\
\text { studies appraised? }\end{array}$ & Yes & No \\
\hline $\begin{array}{l}\text { Were the included studies } \\
\text { sufficiently valid for the type of } \\
\text { question asked? }\end{array}$ & Yes & No \\
\hline $\begin{array}{l}\text { Were the results of the selected } \\
\text { studies similar to each other? }\end{array}$ & Yes & No \\
\hline \multicolumn{3}{|l|}{ Importance } \\
\hline $\begin{array}{l}\text { What are the overall results of the } \\
\text { meta-analysis? }\end{array}$ & $\begin{array}{l}\text { Treatment with } N \text {. sativa has a significant effect on lowering } \\
\text { systolic blood pressure (WMD: }-3.26 \mathrm{mmHg} \text {, 95\% CI: }-5.10 \text {, } \\
-1.42, \mathrm{I}^{2}=59 \% \text { ) and diastolic blood pressure (WMD: }-2.80 \\
\mathrm{mmHg}, 95 \% \mathrm{CI}:-4.28,-1.32, \mathrm{I}^{2}=60 \% \text { ) }\end{array}$ & $\begin{array}{l}\text { Four out of nine studies have shown that } N \text {. } \\
\text { sativa can reduce blood pressure. The } \\
\text { effect however was not significant in the } \\
\text { other five trials }\end{array}$ \\
\hline How precise were the results? & $\begin{array}{l}\text { Precise, with } 95 \% \text { CI for reduced blood pressure after } \\
\text { treatment with N. sativa }\end{array}$ & No statistical data were given in the review \\
\hline \multicolumn{3}{|l|}{ Applicability } \\
\hline $\begin{array}{l}\text { Can the results be applied to our } \\
\text { patient? }\end{array}$ & Yes & No \\
\hline $\begin{array}{l}\text { Were all the clinically important } \\
\text { outcomes considered? }\end{array}$ & Yes & No \\
\hline Do the benefits outweigh the harm? & Yes & Benefits cannot be concluded \\
\hline
\end{tabular}

Owing to the design of the single-blind, non-randomized clinical trial by Badar, et al. [13], its validity is weaker compared with the doubleblind, randomized controlled trial by Rizka, et al. [14] Nevertheless, the validity of the study by Rizka, et al. [14] is also limited by the unknown significance in group similarity and the short duration of treatment. In both clinical trials, those lost to follow-up or dropping out were below $20 \%$, and thus had little effect on their validity. The changes in systolic and diastolic blood pressures at the end of the trial compared with the baseline were taken into account to determine the clinical importance. Only the change in systolic blood pressure of more than $10 \mathrm{mmHg}$ in the study by Rizka et al. [14] was of clinical importance. Meanwhile, the P values of differences in the systolic and diastolic blood pressures between the treatment group and the placebo group were considered to determine its statistical significance. Only the $\mathrm{P}$ value for the difference in diastolic blood pressure in the study by Badar et al. [13] was less than 0.05, and thus statistically significant. Overall, both studies were weak in validity as only one out of four parameters was met in each study. Both clinical trials were considered to be applicable though because of their apparent feasibility of treatment and the benefits over the reported harms. Moreover, the study by Badar, et al. [13] was considered stronger with a higher patient similarity and a narrower range of age and blood pressures. In the study by Rizka, et al. [14], the patients were elderly with a mean systolic blood pressure of 160 $\mathrm{mmHg}$, which was higher than that in the study by Badar, et al.

The meta-analysis by Sahebkar, et al. [15] was valid, relevant, important, and applicable to our question and showed a level of evidence of 1a. Sahebkar, et al. [15] included all valid studies (RCTs, published before 30 August 2015) to determine the effect of $N$. sativa on lowering blood pressure. The study analyzed differences in blood pressure reduction using $\mathrm{I}^{2}$ index and $\mathrm{X}^{2}$ statistics, measuring inter-study heterogeneity. Each study included in the meta-analysis was assessed for publication bias using Egger's test and no bias was 
found. Importance was met with $-3.26 \mathrm{mmHg}, 95 \% \mathrm{CI}:-5.10,-1.42$, $\mathrm{I}^{2}=59 \%$ for SBP and weighted mean difference: $-2.80 \mathrm{mmHg}, 95 \%$ CI: $-4.28,-1.32, \mathrm{I}^{2}=60 \%$ for DBP. Meanwhile, we concluded that the systematic review by Mohtashami, et al. [16] was not valid or applicable to our question. The study was not focused on blood pressure but rather on blood parameters and anthropometric indices. Mohtashami, et al. [16] was unable to make a conclusion on the effects of $N$. sativa on reducing blood pressure because of the different characteristics across the selected studies.

\section{DISCUSSION}

Considering the validity components, the clinical study by Badar, et al. [13] may not suffice. Although there was group similarity in this study, the groups were not assigned randomly. Together with the single-blind design, this poses a notable risk of bias in the study thereby reducing its validity. Meanwhile, the study by Rizka, et al. [14] claimed to have comparable baseline characteristics in the two groups, there were no statistical data presented to indicate statistical significance. While this may decrease the validity of the study to a certain extent, it could still be more valid with its doubleblind design than the study by Badar, et al. [13]

In terms of importance, both clinical trials seemed weak as only one out of four parameters favored the treatment using $N$. sativa. Notably however, in both studies, changes in blood pressure and the $\mathrm{P}$ values of difference between the treatment group and placebo were the only values available for appraisal of importance. The relative risk and the number needed to treat could not be obtained without any data on the event rates. Both studies only presented the mean values of systolic and diastolic blood pressure in the treatment and placebo groups, without specifying the number of events of hypertension in each group. This means that the ratio of benefit and harm in the treatment using Nigella sativa cannot be quantified. These inevitably result in a suboptimal appraisal of the importance of these clinical trials. As for their applicability, both studies presented adequate evidence in favor of using $N$. sativa in patients with hypertension, mainly because of the feasibility and safety. $N$. sativa is easily found in Indonesia and has been empirically used in Indonesia as dietary supplements [17]. The reported adverse events in both studies were minimal, hence strengthening their applicability. The study by Rizka, et al. [14] is, however, less applicable to our question because their patients were elderly with a mean SBP of $160 \mathrm{mmHg}$. Our patient is a middle-aged man with mild hypertension of SBP of $130 \mathrm{mmHg}$. The difference in blood pressures may be clinically significant and may affect the translation of the results to our patient.

The review by Sahebkar, et al. [15] was shown to be valid because of its focus on the question asked, appropriate inclusion criteria, similar results between studies, and good coverage of the included studies. Eleven studies were included, ranging from treatment duration of 4-12 w with both hypertensive and normotensive patients. No publication bias was identified in all 11 studies. Random effect models were used when comparing with a control group, concluding that the group receiving $N$. sativa had a mean decrease of 3.26 and $2.80 \mathrm{mmHg}$ in systolic and diastolic blood pressures, respectively. The effect was also found to be important in lowering blood pressure in human, but the reduction of 3.26/2.80 $\mathrm{mmHg}$ was not clinically significant in controlling hypertension. Besides, the study was conducted in a heterogeneous population with patient differences in demographics and baseline clinical characteristics. It was also limited by the short duration of the included studies, which only ranged from 4 to $12 \mathrm{w}$, and hence was not indicative for the effect of long-term use of $N$. sativa.

In contrast, the systematic review made by Mohtashami, et al. [16] demonstrated low validity. This judgment was based on the lack of information about how the authors concluded the effects of each included trial. Moreover, no statistical data were provided by Mohtashami, et al. [16] making results in the study less important.

Among the four studies considered, we concluded that the metaanalysis by Sahebkar, et al. [15] was the strongest evidence available for our research question owing to its relatively high validity, importance, and applicability.
Unfortunately, the mechanism of how $N$. sativa reduces blood pressure is not well defined. Several factors can be assumed to play a role in this mechanism based on the components of $N$. sativa. Thymoquinone acts on serotoninergic and muscarinic receptors, thymol acts on calcium ion channels, and other components induce diuretic effects through mediating signaling pathways [18-20]. Thymoquinone, flavonoids, and polyphenols also have antioxidant activity that dilates blood vessels by nitric oxide production [21-23]. Furthermore, N. sativa also lowers blood pressure via the diuretic effect; the effect of a dose of $5 \mathrm{mg} / \mathrm{kg}$ of $N$. sativa was comparable with that of furosemide, a frequently used diuretic. This diuretic effect helps to decrease blood pressure through reduction of electrolytes and water content, thus reducing cardiac output [24]. However, these results were obtained in a strict, laboratorycontrolled environment; hence, their proposed mechanisms must be interpreted with caution. The exact mechanism of action of $N$. sativa is therefore still indefinite.

The limitation of this study is that in the appraisal of the importance of the clinical trials, the relative risk and the number needed to treat could not be assessed owing to the lack of data of the event rates in the two clinical trials. The data were unpublished and we have yet to be in correspondence with the authors of these studies for the relevant data. In general, we have also found that the use of $N$. sativa in alleviating high blood pressure is relatively unexplored, resulting in the limited number of studies available. We hope that this study will prompt more clinical trials on the use of $N$. sativa in treating hypertension, which will help to determine its effects on blood pressure and its safety during long-term use.

As for the patient in our case, the recommended management based on the 2017 ACC/AHA guidelines is nonpharmacologic therapy and reevaluation in 3-6 mo after starting therapy [4]. Nonpharmacologic therapy may include a combination of changes in diet and physical activity. As for the use of $N$. sativa supplements to control hypertension, we have to explain to the patient that the current evidence is still limited, despite a favorable tendency towards the antihypertensive effects. The patient can also be educated on the importance of a balanced diet, physical activity, and routine health check-up.

\section{CONCLUSION}

In conclusion, the current evidence for the use of $N$. sativa in lowering blood pressure is still limited, with the strongest evidence for its significant antihypertensive effect from a meta-analysis of RCTs. Other clinical trials also suggested clinically significant decreases in systolic blood pressure. Considering its benefits of alleviating hypertension and its relatively few reported side effects, further research is encouraged to achieve a better understanding of the use of $N$. sativa as antihypertensive treatment and to provide high-quality evidence to support healthcare policies and clinical decisions. This should benefit millions of people affected by hypertension and cardiovascular diseases worldwide.

\section{ACKNOWLEDGMENT}

We thank all the staff of the Department of Medical Pharmacy in the Faculty of Medicine of Universitas Indonesia for the opportunity to prepare this report. This article was presented at The $3^{\text {rd }}$ International Conference and Exhibition on Indonesian Medical Education and Research Institute (ICE on IMERI 2018), Faculty of Medicine, Universitas Indonesia, Jakarta, Indonesia. We thank the $3^{\text {rd }}$ ICE on IMERI Committee who had supported the peer review and manuscript preparation before submitting to the journal.

\section{AUTHORS CONTRIBUTIONS}

\section{All the author have contributed equally}

\section{CONFLICTS OF INTERESTS}

There is no conflict of interest in the preparation and publication of this study.

\section{REFERENCES}

1. World Health Organization. WHO Raised blood pressure. Who.int; 2018. Available from: http://www.who.int/gho/ 
ncd/risk_factors/blood_pressure_prevalence_text/en/. [Last accessed on 02 Oct 2018]

2. Badan Penelitian dan Pengembangan Kesehatan. Riset Kesehatan Dasar 2013. Jakarta: Kementrian Kesehatan Republik Indonesia; 2013.

3. Kementrian Kesehatan Republik Indonesia. Sebagian Besar Penderita Hipertensi tidak Menyadarinya. Depkes.go.id; 2017. Available from: http://www.depkes.go.id/article/view/ 17051800002/sebagian-besar-penderita-hipertensi-tidakmenyadarinya.html. [Last accessed on 02 Oct 2018]

4. Whelton PK, Carey RM, Aronow WS, Casey DE, Collins KJ, Himmelfarb $\mathrm{CD}$, al. 2017ACC/AHA/AAPA/ABC/ACPM/AGS/APhA/ASH/ASPC/NM A/PCNA Guideline for the prevention, detection, evaluation, and management of high blood pressure in adults: a report of the American College of Cardiology/American Heart Association Task Force on clinical practice guidelines. J Am Coll Cardiol 2018;71:e127.

5. Tedla YG, Bautista LE. Drug side effect symptoms and adherence to antihypertensive medication. Am J Hypertens 2016;29:772-9.

6. Morgado M, Rolo S, Macedo AF, Pereira L, Castelo-Branco M. Predictors of uncontrolled hypertension and antihypertensive medication nonadherence. J Cardiovasc Dis Res 2010;1:196-202.

7. Gu Q Burt VL, Paulose Ram R, Yoon S, Gillum RF. High blood pressure and cardiovascular disease mortality risk among U. S. adults: the third National Health and Nutrition Examination Survey mortality follow-up study. Ann Epidemiol 2008;18:302-9.

8. Disi SS, Anwar MA, Eid AH. Anti-hypertensive herbs and their mechanisms of action: part I. Front Pharmacol 2015;6:323.

9. Salem ML. Immunomodulatory and therapeutic properties of the Nigella sativa L. seed. Int J Immunopharmacol 2005;5:1749-70.

10. Ubru U, Burak U, Yusuf S, Reyhan B, Arif K, Faruk TH. Cardioprotective effects of Nigella sativa oil on cyclosporine ainduced cardiotoxicity in rats. Basic Clin Pharmacol Toxicol 2008;103:574-80.

11. Mathur ML, Gaur J, Sharma R, Haldiya KR. Antidiabetic properties of a spice plant Nigella sativa. J Endocrinol Metab 2011;1:1-8.

12. Nader MA, El-Agami DS, Suddek GM. Protective effects of propolis and thymoquinone on development of atherosclerosis in cholesterol-fed rabbits. Arch Pharm Res 2010;337:637-43.
13. Badar A, Kaatabi H, Bamosa A, Al-Elq A, Abou-Hozaifa B, Lebda $\mathrm{F}$, et al. Effect of Nigella sativa supplementation over a one-year period on lipid levels, blood pressure and heart rate in type-2 diabetic patients receiving oral hypoglycemic agents: nonrandomized clinical trial. Ann Saudi Med 2017;37:56-63.

14. Rizka A, Setiati S, Lydia A, Dewiasty E. Effect of Nigella sativa seed extract for hypertension in elderly: a double-blind, randomized controlled trial. Acta Med Indones 2017:49:7.

15. Sahebkar A, Soranna D, Liu X, Thomopoulos C, Simental Mendia LE, Derosa G, et al. A systematic review and meta-analysis of randomized controlled trials investigating the effects of supplementation with Nigella sativa (black seed) on blood pressure. J Hypertens 2016;34:2127-35.

16. Mohtashami A, Entezari M. Effects of nigella sativa supplementation on blood parameters and anthropometric indices in adults: a systematic review on clinical trials. J Res Med Sci 2016;21:3.

17. Herlina, Aziz SA, Kurniawati A, Faridah DN. Changes of thymoquinone, thymol, and malondialdehyde content of black cumin (Nigella sativa L.) in response to Indonesia tropical altitude variation. HAYATI J Biosci 2017;24:156-61.

18. Teres S, Barcelo Coblijn G, Benet M, Alvarez R, Bressani R, Halver JE, et al. Oleic acid content is responsible for the reduction in blood pressure induced by olive oil. Proc Natl Acad Sci 2008;105:13811-6.

19. Tahir KE, Ashour MM, Al-Harbi MM. The cardiovascular actions of the volatile oil of the black seed (Nigella sativa) in rats: elucidation of the mechanism of action. Gen Pharmacol 1993;24:1123-31.

20. Tahir KE, Ageel AM. Effect of volatile oil of Nigella sativa on the arterial blood pressure and heart rate of the guinea pig. Saudi Med J 1994;2:163-8.

21. Peixoto Neves D, Silva Alves KS, Gomes MD, Lima FC, Lahlou S, Magalhaes PJ, et al. Vasorelaxant effects of the monoterpenic phenolisomers, carvacrol and thymol, on rat isolated aorta. Fundam Clin Pharmacol 2010;24:341-50.

22. Andriambeloson E, Magnier C, Haan Archipoff G, Lobstein A, Anton R, Beretz A, et al. Natural dietary polyphenolic compounds cause endothelium-dependent vasorelaxation in rat thoracic aorta. J Nutr 1998;128:2324-33.

23. Zaoui A, Cherrah Y, Lacaille Dubois MA, Settaf A, Amarouch H, Hassar M. Diuretic and hypotensive effects of Nigella sativa in the spontaneously hypertensive rat. Therapie 2000;55:379-82. 